\title{
Investigating the Asymmetry Effects of Crude Oil Price on Renewable Energy Consumption in the United States
}

\section{Pritish Sahu ( $\sim$ pritishkumar9@gmail.com )}

Bimtech Bhubaneswar: Birla Institute of Management Technology https://orcid.org/0000-0002-86396864

\section{Sakiru Adebola Solarin}

University of Nottingham - Malaysia Campus

\section{Usama Al-mulali}

Multimedia University - Melaka Campus: Multimedia University

Ilhan Ozturk

Cag Universitesi

\section{Research Article}

Keywords: oil prices, renewable energy, GDP, trade openness, Asymmetries, NARDL

Posted Date: April 21st, 2021

DOl: https://doi.org/10.21203/rs.3.rs-321655/v1

License: (c) (i) This work is licensed under a Creative Commons Attribution 4.0 International License. Read Full License

Version of Record: A version of this preprint was published at Environmental Science and Pollution Research on August 3rd, 2021. See the published version at https://doi.org/10.1007/s11356-021-155779. 


\title{
Title Page
}

Investigating the Asymmetry Effects of Crude Oil Price on Renewable Energy Consumption in the United States

\author{
Pritish Kumar Sahu \\ Corresponding author \\ School of Management, Birla Global University, Bhubaneswar, \\ Odisha 751029, India. Email: pritish.sahu@bgu.ac.in
}

$\underline{\text { Ph: }+91-7381733187}$

ORCID: https://orcid.org/0000-0002-8639-6864

\begin{abstract}
Sakiru Adebola Solarin
School of Economics, University of Nottingham Malaysia, Jalan Broga, 43500 Semenyih Selangor Darul Ehsan, Malaysia.

Email: sakirusolarin@gmail.com

\section{Usama Al-mulali}

Faculty of Business, Multimedia University, 75450 Melaka, Malaysia. Email: usama.almulali@mmu.edu.my

ORCID: http://orcid.org/0000-0001-6431-7873
\end{abstract}

\section{Ilhan OZTURK}

Faculty of Economics and Administrative Sciences, Cag University, 33800, Mersin, Turkey. Email: ilhanozturk@cag.edu.tr ORCID: https://orcid.org/0000-0002-6521-0901 


\begin{abstract}
The reduction in oil prices might make crude oil a cheaper alternative to renewable energy. Given this, the present paper examines the effect of fluctuation of oil prices on the use of renewable energy in the United States during the period 1970-2019. We constructed two nonlinear Autoregressive Distributed Lag (NARDL) models to examine the effect of the positive and negative oil prices shocks on the use of renewable energy in the US. The renewable energy consumption is taken as the dependent variable and GDP, Brent crude prices, population density, trade openness and price index as independent variables. The result revealed that the rise in crude oil price, GDP and population density will increase renewable energy use in the short run and in the long run as well. Moreover, the study finds that any decrease in oil prices will decrease renewable energy use in the short run and its effect will eventually diminish in the long run.
\end{abstract}

Keywords: oil prices; renewable energy; GDP; trade openness; Asymmetries; NARDL

\title{
1. Introduction
}

In the last four decades, the dependency on energy increased much faster than ever before. The world witnessed a paradigm shift in the use of the source of energy, from wind, water and coal to oil and natural gas during this period. The fossil fuel played a substantial role in the source of modern energy generation as most of the traditional energy generating sources was replaced. However, rise in the prices of oil and the environmental consequences of greenhouse gas emissions raised many eyebrows about the alternative source of energy, a replacement to the use of crude oil. More than a decade now, the renewable sources of energy have increased its importance across the globe including in the United States of America (USA). The political commitment of G7 countries and the European Union for achieving the future sustainability in the energy through the availability of renewable energy shows its importance (EC News, May 2015). Even the renewable energy initiatives of the G7 countries aims at making the energy accessible to all in the African region by improving the renewable energy by 2030 (UN 2015). 
Many countries started to encourage the use of the alternative source of energy and supported the technological innovation, mechanism and policies to enhance the production of renewable energy (Dogan et. Al. 2021). The prime objective of these efforts is to increase the availability of energy for all through the global renewable energy system at a cheaper and affordable price along with protecting the environment. As it is a cheaper alternative and has low carbon emission, the United States has witnessed a rise in both production and consumption of renewable energy in recent years (World Bank 2020). Even the expansions of renewables often surpassed the expected target (Schmalensee et al. 2015) and in particular, the growth of solar energy has surpassed the target and projection of International Energy Agency's (IEA). While the production and the supply of renewables is in rising trend, the fluctuation in the price of crude oil, in particular, a decrease in crude oil prices has left several questions unanswered in the hands of the academia and policy makers. It is evident that between 2011 and 2020 (April), the prices of the crude oil declined from a high of about $\$ 120$ per barrel to as low as $\$ 21$ per barrel. Though the oil price has increased thereafter but in general, the declining trend in the oil prices in the last one decade might affect the demand for renewable energy and derail the ambition of a carbon free energy future.

To be precise, the falling price of the crude oil might create two possibilities; the first possibility is based on the notion that any fall in the prices of crude oil would increase the demand of it. This might have some serious consequences on the future demand for renewable energy. In other words, a reduced oil price would again increase the demand of oil, substituting the alternative use of the renewable resources in the United States. The second possibility is that, the cheaper the crude oil, the more funds that the country will have to promote renewable energy projects which, in turn, increase the renewable energy sources demand. Consequently, based on these two possibilities, this paper is motivated to investigate whether the increase or the decrease in crude oil prices would affect the demand for renewable energy in the United States.

The United States is world's largest crude oil consumer and the second-largest producer of CO2 emission. Therefore, moving toward crude oil might have serious consequences on world environmental degradation. Moving toward renewable energy sources is important to compact 
greenhouse gas emission that mostly comes from the consumption of fossil fuels. Therefore, the core objective of this research is to explore the impact of oil price fluctuations on the use of renewable energy in the United States.

The renewable energy consumption in US is in increasing trend. US is among the few countries in the world having the best resources along with the knowledge of innovation and the financing abilities. Since the beginning of late $18^{\text {th }}$ century, fossil fuel played a major role as the source of energy for the US economy. However, the increased concern about the greenhouse gas emissions and the realization of US to be a major global player in the production and consumption of the cleaner energy has shifted the outlook since the beginning of the current century.

Towards the late nineties, the energy consumption in US shifted for renewable energy source, mostly derived from the wind, solar and bio fuels. The share of renewable energy in the total energy consumption in US increased from just about $3 \%$ in late nineties to $7.5 \%$ in 2010 and to $11 \%$ in 2019 . The international Renewable Energy Agency (IRENA) predicts that the share of renewable energy in US could increase to $27 \%$ by the year 2030 with more than $50 \%$ alone from the power sector. The power sector which accounted more than 55\% in the total energy consumption at present shows an increasing share of it is generated from the renewable sources.

With certain assumptions, in 2020, the US Energy Information Administration forecasts that the renewable energy production would increase from $18 \%$ in 2019 to $31 \%$ in 2050 . The electric power sector, the largest source of energy to the US has undergone a drastic shift in its production from the fossil fuel and nuclear power to the wind and solar sources. Data shows, the share of the renewables in electricity production registered an increase from $11 \%$ in 2010 to $14 \%$ in 2014 and $20 \%$ in 2020 . With the increased renewable electricity production and continuous fall in the prices of the natural gas, the wholesale prices of the electricity has fallen in the US market. The increased production of the renewable energy and a fall in the prices of natural gas and other petroleum products could pose a threat to the consumption of the renewables. However, data shows a satisfactory trend in the consumption of renewable energy as it has increased from $6.5 \%$ in 2007 to more than $12 \%$ in 2019 . Over the years, the development of technology, declining cost and improving performance is making solar and wind more popular and competitive compared to other sources of energy. The production of 
energy (e.g. electricity) from these sources will minimize the emission, reduce cost and its supply is unlikely to decline over time.

The policies in regard to the renewable energy at the state and at the central level are also encouraged and implemented so as to popularize its use. Number of states such as California, New Jersey and Massachusetts has enacted new laws for renewable energy supply and consumption. E.g. policies enacted by California to supply $100 \%$ cleaner energy by 2045, New Jersey and Massachusetts has prepared the footprint to make $50 \%$ and $35 \%$ of the energy production from the renewable sources respectively. The effort of these governments could increase the production of the renewable; however, the use of the renewable will primarily depend upon the prices of the available alternative energy and the strictness of the law in future.

What motivates this study is the following; despite the extensive number of studies, we have not come across any specific study which examines the relation between the crude oil prices and renewable energy in the US. Rather, majority of the existing studies used the panel data to find an overall result for a group of countries (Inglesi-Lotz and Dogan 2018; Erdogan et al 2020; Mujataba and Jena 2021 etc.) instead of any particular country.

Given the fact that each country has different economic characteristics, panel result might not deliver a clear or an accurate conclusion. Moreover, majority of the studies examined the positive effect of oil price shocks (linear effect of oil prices) on renewable energy by ignoring the negative effect of oil price shocks. Given this, the present study used the nonlinear ARDL model to find the nonlinearity effects of oil prices (increase or decrease) on renewable energy use in the United States.

\section{Literature review}

There are sizeable numbers of research that examined the main macroeconomic determinants that impact energy use in general. The most utilized factors are GDP growth (Omri and Kahouli 2014; Kyophilavong et. al. 2015; Rafindadi and Ozturk 2016; Shahbaz et al. 2016; Dogan and Aslan 2017; Ben et al. 2019 and so forth). The relationship between GDP growth on air pollution is well-examined by the previous studies and the effects are clear. The previous studies reached mostly to the 
conclusion that the increase in economic activates increases environmental degradation mostly in developing and emerging economies than the developed economies. This can be linked to the environmental Kuznets Curve (EKC) hypothesis; at the early stages of economic developed the country is basically a polluting industrial based economy until a certain stages of economic development the economy will transform in to clean service based economy. Moreover, when income gets higher citizens will have more preference for better environmental quality (Dinda 2004; Erdogan et al. 2020).

Foreign direct investment is a widely utilized pollution indicator (Omri and Kahouli 2014; Mudakkar 2013; Azam et al. 2015; Khan and Ozturk 2020; Abdo et al. 2020). Foreign direct investment (FDI) can have different effects on environmental degradation depends on the type of investment. Basically, large industrialized countries tend to send their dirty factories to less developed nations with less string environmental regulations, cheap labor and resources. Therefore, FDI increases environmental degradation mostly in less developed countries than the developed ones. Similarly, the development of the financial institution is proven to be an important indicator of environmental degradation (Sadorsky 2010; Zaidi et al. 2019; Nasir et al, 2019 and so forth).

Population is an important indicator of environmental degradation as the world population is growing rapidly far more than the earth's ability to support. Therefore, the rise in population has proven to increase environmental degradation in most of the countries (Omri and Kahouli 2014; Azam et al. 2015; Liu et al. 2019 and so forth). Despite the differences in methodologies and the countries concerned, most of the existing studies have established that the variables such as GDP, FDI, financial institutions and population has significant consequence on the use of energy. Besides these, the impact of energy prices on the energy consumption is not new, rather examined by many scholars in their empirical analysis (Sadorsky 2010; Aguirre and Ibikunle 2014; Murshed and Tanha 2020; Apergis et al. 2021). 
The emphasis on the key influences of renewable energy use is relatively a newly focused area. Much less is known about the impact of energy price, particularly the oil price, on renewable energy use though several other aspects of the renewable energy is studied and debated intensively. In context to the relation between the oil price and the renewable energy, Omri et al. (2015), Aguirre and Ibikunle (2014), Ferrer et al. (2018), Cao et al. (2019) found that oil price negatively affects the renewable energy consumption and investment. Majority of these studies investigating the relationship between the oil price and the use of renewable energy takes a panel of countries rather than a single country into analysis. Study by Coban and Topcu (2013) while studying in context of the EU27 countries finds a negative relation of oil price with the renewable energy demand. Aguirre and Ibikunle (2014) study on 38 countries of the EU OECD and BRICS finds that oil price have a marginal negative impact on consumption of renewable energy. Doytch and Narayan (2016) study involving 74 countries shows the evidence of negative influence of index of energy prices on the renewable energy consumption in the model based on Blundell-Bond dynamic panel estimator. Bondia et al. (2016) study in a multivariate framework finds that in the long run, oil prices have no effect on the renewable energy consumption but influences it in the short run. Dogan et al. (2021) finds that oil price has weak relation with renewable energy consumption than the renewable energy production.

Though most of these studies find a weak or negative relationship between the oil price and the use of renewable energy, but the intensity of it varies differently in different studies. Despite the evidence of a negative relationship between the two variables, these studies fail to provide a clear explanation behind such relationship. On the other hand, some of these studies suggested the reason for such negative relationship could be due to a small sample size, some other suggests that the relationship is because of the nature and pattern of energy consumption of these countries, industrial or otherwise. Moreover, some other scholars suggested that the negative relationship between the two variables is because of the fact that the crude oil and renewable energy are compliment goods. However, scholars such as Lin and Omoju (2017) found that the surge in oil prices resolve an increase in the demand for renewables. The reason behind such relationship is because renewable energy sources are a substitute for crude oil, therefore the rising prices of crude oil will make renewable energy a cheaper alternative. 


\section{Methodology}

\subsection{Model and data}

Relying on the findings of past studies (Çoban and Topcu 2013; Doytch and Narayan 2016 and Mujtaba and Jena 2021), we utilised the following two models specification (to examine the robustness of the results) to examine the variables that determine renewable energy consumption during the period 1970-2019. Different from the previous studies the nonlinear ARDL is utilized to examine the effects of the positive and the negative shocks in oil prices on renewable energy consumption.

$$
\begin{aligned}
& \ln R E t=\alpha 1+\alpha 2 \ln O P t+\alpha 3 \ln G D P t+\alpha 4 \ln P D t+\alpha 5 \ln P I t+\varepsilon t \\
& \ln R E t=\alpha 1+\alpha 2 \ln O P t+\alpha 3 \ln G D P t+\alpha 4 \ln T R D t+\alpha 5 \ln P I t+\varepsilon t
\end{aligned}
$$

Here, $\ln R E$ is the natural $\log$ of renewable energy consumption (millions of kilowatt-hours), $\ln O P$ is the natural $\log$ of Brent crude price (US\$ per barrel), $\ln P D$ is the natural $\log$ of population density (per sq. $\mathrm{km}$ of land area), $\operatorname{lnTRD}$ is the natural $\log$ of trade openness measured in millions of constant US dollars and $\ln P I$ the natural $\log$ of price index and $\varepsilon_{t}$ is error term with the assumption of normal distribution ${ }^{1}$.

The model above represents basic renewable energy consumption. This model contains GDP as an indicator of income, price index; since changes in the price level might affect the demand (consumption) of renewable energy. Moreover, the price of crude oil is also included which represents the price of an alternative source of energy, the increase in crude oil prices will make renewables a more attractive alternative. Population density is a determining factor of renewable energy as the increase in population will increase energy use in general. Therefore, high population density might increase the consumption of renewable energy. Moreover, the increase in the country's price level will cause a decline the consumer purchasing power which will cause a reduction in the consumption of renewable energy.

\footnotetext{
${ }^{1}$ Since the price of renewable energy is not available, we have followed the work of $\mathrm{Li}$ and $\mathrm{Lin}$ (2016) to use the producer price index as a proxy for the price of renewable energy.
} 
The data of renewable energy consumption per capita was obtained from Energy Information Administration (2020), GDP, Brent crude oil prices, population density, and price index were retrieved from the World Development Indicators (2020) and trade openness is obtained from the OECD database (2020).

\subsection{Residual augmented least squares (RALS) unit root test}

The first step is to check the stationarity; therefore, the RALS unit root test of Meng et al. (2014) is used. The specification of the model is as follows

$$
\Delta y_{t}=\delta^{\prime} \Delta Z_{t}+\phi S_{t-1}^{\sigma}+\sum_{j=1}^{k} d_{j} \Delta S_{t-j}^{O}+\hat{w}_{t}^{\prime} \gamma+u_{t}
$$

The null of non-stationarity is based on $\phi=0$ and the ordinary least square approach is utilised to generate the tests statistic. $Z_{t}$ is a vector that houses the exogenous variables, which is expressed as $Z_{t}=\left[1, t, D_{1 t}^{*}, \ldots, D_{R t}^{*}, D T_{1 t}^{*}, \ldots, D T_{R t}^{*}\right]^{\prime}$. Whereas, the dummy $D_{1 t}^{*}=1$ for $\mathrm{t} \geq T_{B}+1, i=1, \ldots, R$, and 0 , otherwise, and $D T_{1 t}^{*}=t-T_{B i}$ for $\mathrm{t}^{\mathrm{t} \geq T_{B}+1}$ and 0 otherwise. ${ }_{B i}$ captures the locations of the breakpoints and $\delta$ are the coefficients that are derived from the regression of $\Delta y_{t}$ on $\Delta Z_{t}{ }^{\beta_{t}^{6}}$ captures the

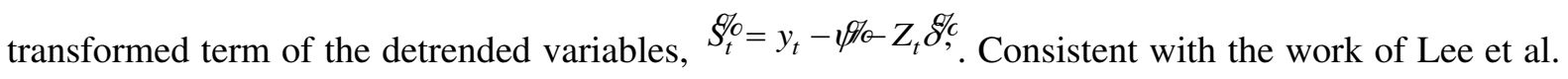
(2012), the transformation is needed to make the method more robust.. $\hat{w}_{t}$ is the information on nonnormal errors and its presence transform the test into a RALS framework. In the Lagrange multiplier (LM) test of Lee et al. (2012), $\gamma=0$. The lagged terms of $\Delta \bar{S}_{t-j}$ are incorporated into the analysis in order to cater for the incidence of autocorrelation ${ }^{2}$.

The next step is to examine the nonlinear ARDL as suggested by Shin et al. (2011) ${ }^{3}$. This test is used to reveal the asymmetric (nonlinear) relationship in the short-run and the long-run. Contrasting earlier studies, the findings of this research reveal whether the short-run and long-run positive shocks of the

\footnotetext{
2 The detailed information on these tests have been documented in Lee et al. (2013) and Meng et al. (2014).

${ }^{3}$ For more details on the nonlinear ARDL method see Shin et al. (2011)
} 
independent variable are similar to the short-run and long-run negative shocks. The nonlinear ARDL models are presented as follows:

$$
\begin{aligned}
& \operatorname{lnR} E_{t}=C+\alpha_{1} \ln G D P_{t}+\alpha_{2} \ln O P_{t}^{+}+\alpha_{3} \ln O P_{t}^{-}+\alpha_{5} \ln P D_{t}+\alpha_{6} \ln P I_{t}+\varepsilon_{t} \\
& \ln R E_{t}=C+\alpha_{1} \ln G D P_{t}+\alpha_{2} \ln O P_{t}^{+}+\alpha_{3} \ln O P_{t}^{-}+\alpha_{5} \ln T R D_{t}+\alpha_{6} \ln P I_{t}+\varepsilon_{t}
\end{aligned}
$$

where, $t$ represent time; ${ }^{-}$and ${ }^{+}$symbolizes the positive and negative shocks for oil prices. $\varepsilon_{t}$ is the error term with the assumption of normal distribution.

\section{Empirical Results}

Before the nonlinear Autoregressive Distributed Lag (NARDL) is utilized it is important to confirm that all the variables are not stationary at the second difference. The unit root tests results confirmed that all the variables are stationary at the first difference, therefore, the NARDL can be performed. The next step is to generate the positive and negative shocks for oil price variables and finally, the NARDL can be performed ${ }^{4}$.

The empirical outcome commenced by testing the unit root structures of the variables, which is described in Table 1. We applied the Meng et al. (2014) unit root test for our assessment; we also reported the results of Lee et al. (2012) test. The procedures suggested by Dawson and Strazicich (2010) are employed to decide on the ideal lag. When the variables are subjected to the RALS test, there is evidence that the series are stationary at first difference. The results from the LM test reported in table 2 are substantially very similar to the output from the RALS test. It is noted that about $30 \%$ are located in the latter parts of 2000s. This is not surprising given the fact that the period largely corresponded with the period of US financial crisis which triggered a worst form of economic recession in the US ever since the great depression of 1930s. To conduct a robustness check for the stationarity tests, we further used two additional unit root tests provided by Kapetanios et al. (2003) and Kruse $(2011)^{5,6}$. The outcomes of the two tests, which are reported in Table 2 are all stationary at first differences.

\footnotetext{
${ }^{4}$ We can run the nonlinear ARDL utilizing the Eviews 9.

${ }^{5}$ These two tests provide for nonlinearity. The detailed information on these tests have been documented in Kapetanios et al. (2003).and Kruse (2011)

${ }^{6}$ Consistent with the advice of Kapetanios et al. (2003), we have used the demeaned version of the test.
} 


\begin{tabular}{lll}
\hline Variables & Kapetanios et al. (2003) & Kruse (2011) \\
\hline $\ln$ REC & $0.365(1)$ & $7.247(1)$ \\
$\Delta \ln$ REC & $-4.295^{* * *}(1)$ & $18.374 * * *(1)$ \\
$\ln$ GDP & $-0.364(2)$ & $2.949(2)$ \\
$\Delta \ln$ GDP & $-4.941^{* * *(1)}$ & $23.997 * * *(1)$ \\
$\ln$ PD & $-0.543(2)$ & $0.400(2)$ \\
$\Delta \ln$ PD & $-3.499 * *(2)$ & $16.301 * *(2)$ \\
$\ln$ OP & $-2.402(1)$ & $6.022(1)$ \\
$\Delta \ln$ OP & $-4.000^{* * *}(1)$ & $17.997 * * *$ \\
$\ln$ PPI & $-2.375(1)$ & $8.284(1)$ \\
$\Delta \ln$ PPI & $-3.499 * * *(1)$ & $14.070^{* * *}(1)$
\end{tabular}

Critical values

\begin{tabular}{lll}
\hline Variables & Kapetanios et al. (2003) & Kruse (2011) \\
\hline $1 \%$ & -3.48 & 13.15 \\
$5 \%$ & -2.93 & 10.17 \\
$10 \%$ & -2.66 & 8.60
\end{tabular}

***and $* *$ and $*$ indicate $1 \%$ and $5 \%$ and $10 \%$ significance level. The maximum lag length is set at 2 since we are using an annual dataset. () contains the optimal lag length. The optimal lag length based on the Aikaike Information Criteria.

Table 2: LM unit root test

\begin{tabular}{|c|c|c|c|c|c|c|c|c|}
\hline Variable & LM stat & RALS stat & $\hat{\rho}^{2}$ & $\mathrm{~TB}$ & & RALS & tical va & \\
\hline & $\tau *_{\mathrm{LM}}$ & $\tau *$ RALS-LM & & Break 1 & Break 2 & $1 \%$ & $5 \%$ & $10 \%$ \\
\hline ln $\mathrm{REC}$ & $-2.520(0)$ & $-3.048(0)$ & 0.811 & 2006 & & -4.104 & -3.548 & -3.268 \\
\hline$\Delta l n \mathrm{REC}$ & $-7.947 * * *(0)$ & $-8.080 * * *(0)$ & 0.871 & 1988 & 2002 & -4.590 & -4.058 & -3.786 \\
\hline $\ln \mathrm{GDP}$ & $-3.768(0)$ & $-3.332(0)$ & 0.986 & 1981 & 2007 & -4.679 & -4.169 & -3.906 \\
\hline$\Delta \ln \mathrm{GDP}$ & $-6.165 * * *(1)$ & $-6.112 * * *(1)$ & 0.983 & 1981 & 2009 & -4.677 & -4.166 & -3.903 \\
\hline $\ln \mathrm{PD}$ & $-3.827(1)$ & $-3.553(1)$ & 0.928 & 1988 & 2008 & -4.639 & -4.113 & -3.846 \\
\hline$\Delta \ln \mathrm{PD}$ & $-3.617 *(1)$ & $-7.669 * * *(0)$ & 0.195 & 2001 & - & -3.346 & -2.698 & -2.354 \\
\hline $\ln \mathrm{OP}$ & $-3.041(0)$ & $-3.532(0)$ & 0.781 & 1984 & 1987 & -4.497 & -3.963 & -3.684 \\
\hline$\Delta \ln \mathrm{OP}$ & $-6.702 * * *(0)$ & $-7.621 * * *(0)$ & 0.760 & 1978 & 1987 & -4.476 & -3.936 & -3.657 \\
\hline ln PPI & $-2.386(0)$ & $-2.553(0)$ & 0.927 & 1983 & - & -4.155 & -3.618 & -3.346 \\
\hline$\Delta \ln \mathrm{PPI}$ & $-8.050 * * *(1)$ & $-7.736 * * *(1)$ & 0.947 & 1998 & 2007 & -4.652 & -4.132 & -3.866 \\
\hline
\end{tabular}

$* * *, * *, *$ denote significance at $1 \%, 5 \%$ and $10 \%$. The critical values are based on the works of Lee et al. (2012) and Meng et al. (2014).

The maximum lag length is set at 2 since we are using an annual dataset. () contains the optimal lag length. 
Once perceiving the integration properties of the variable, we proceeded with the nonlinear ARDL test to inspect possible long-run link in the series. Therefore, the bound test for cointegration is implemented, the outcomes are revealed in Table 3. The outcomes show the F-statistics is 9.287871 for model 4 and 4.539995 for model 5 which is greater than the critical values of I0 Bound and I1 Bound at the entire levels of significance rejecting the null hypothesis of no cointegration. Therefore, it is clear that the long-run link exists among the estimated variables in both models.

Table 3: Bound test

\begin{tabular}{|c|c|c|}
\hline \multicolumn{3}{|l|}{ Model (4) } \\
\hline Test Statistic & Value & $\mathrm{k}$ \\
\hline F-statistic & 9.287871 & 5 \\
\hline \multicolumn{3}{|c|}{ Critical Value Bounds } \\
\hline Significance & I0 Bound & I1 Bound \\
\hline $10 \%$ & 2.08 & 3 \\
\hline $5 \%$ & 2.39 & 3.38 \\
\hline $2.5 \%$ & 2.7 & 3.73 \\
\hline $1 \%$ & 3.06 & 4.15 \\
\hline \multicolumn{3}{|l|}{ Model (5) } \\
\hline Test Statistic & Value & $\mathrm{k}$ \\
\hline F-statistic & 4.539995 & 5 \\
\hline \multicolumn{3}{|c|}{ Critical Value Bounds } \\
\hline Significance & I0 Bound & I1 Bound \\
\hline $10 \%$ & 2.08 & 3 \\
\hline $5 \%$ & 2.39 & 3.38 \\
\hline $2.5 \%$ & 2.7 & 3.73 \\
\hline $1 \%$ & 3.06 & 4.15 \\
\hline
\end{tabular}


As cointegration is present the short run and long run estimations of the nonlinear ARDL can be performed. The short-run and long-run estimation are obtained in Table 4 and 5; the short-run results reveal that the rise in oil prices will increase renewable energy use while the fall in oil prices will reduce the use of renewable energy. Moreover, the GDP, population density and trade openness will increase renewable energy consumption significantly. However, the increase in price index will decrease the renewable energy consumption significantly.

The following is to perform the long run estimation. The results in table 4 for model 4 were similar to the short-run outcomes as the increase in oil prices, GDP, population increase renewable energy use. However, the rise in price level decreases the use of renewable energy. Moreover, the results revealed that the effect of the decrease in oil prices on renewable energy consumption will diminish in the long run.

Table 4: short run and long run non-linear ARDL estimation (model 4)

\section{Short run estimation}

Variable

F-statistics value

Probability

\begin{tabular}{lll}
\hline In $O P+$ & $25.55883^{* * *}$ & 0.0013 \\
Ln $O P-$ & $-5.346396^{* *}$ & 0.0416 \\
In $G D P$ & $15.17668^{* * *}$ & 0.0043 \\
ln $P D$ & $3.960614 *$ & 0.0745 \\
Ln $P I$ & $-18.73819^{* * *}$ & 0.0028 \\
\hline
\end{tabular}

long-run estimation

\section{Positive}

\begin{tabular}{lll}
\cline { 2 - 3 } Variable & t-statistics & Probability \\
\hline $\ln \mathrm{OP}+$ & $3.686795^{* *}$ & 0.0142 \\
$\ln \mathrm{OP}-$ & -0.173976 & 0.8687 \\
$\ln \mathrm{GDP}$ & $4.652223^{* * *}$ & 0.0056 \\
$\ln \mathrm{PD}$ & $3.196943^{* *}$ & 0.0241 \\
$\operatorname{Ln} \mathrm{PI}$ & $-5.573572 * * *$ & 0.0026 \\
\hline
\end{tabular}


Diagnostics Test: $\quad$ Statistics value Probability

Serial Correlation LM Test: $0.792993 \quad 0.4607$

Heteroskedasticity Test $\quad 1.366285 \quad 0.3957$

$\begin{array}{lll}\text { Normality Test } & 0.409655 & 0.81478\end{array}$

We use the Breusch-Godfrey test for the serial correlation test, Breusch-Pagan-Godfrey test for the heteroskedasticity test and Jarque-Bera for the normality test.

The long run results presented in table 5 for model 5 shows different outcomes as the increase in oil price, the decrease in oil prices, GDP losses their significance in the long run. Conversely, trade openness and price level have a significant positive and negative effect on renewable energy consumption in the long run.

The results (based on model 4) revealed that the increase in oil prices (similar outcomes to Lin and Omoju, 2017), GDP (similar results were found by Doytch and Narayan, 2016; Rafindadi and Ozturk, 2016; and Rafindadi and Ozturk, 2016) and population density (similar outcome to Omri and Kahouli, 2014; Azam et al., 2015) will have a permanent effect in increasing renewable consumption in the United States. On the other hand, the rise in the price level (both model 4 and 5) will reduce the United States consumption of renewable energy (similar to Doytch and Narayan, 2016). Moreover, the results for model 5 revealed that trade openness positively contributing to the increase in renewable energy consumption in the short run and the long run (similar results were found by Omri and Nguyen, 2014 and Omri et al., 2015). Lastly, the results show that the decrease in oil prices will affect renewable energy consumption in the short run but its effect will diminish in the long run. Therefore, the decrease in oil price will have a permanent effect on the United States renewable energy consumption.

Table 5: short run and long run non-linear ARDL estimation (model 5)

Short run estimation

\begin{tabular}{lll}
\hline Variable & F-statistics value & Probability \\
\hline $\ln O P+$ & $46.67751^{* * *}$ & 0.0047
\end{tabular}




$\begin{array}{lll}\text { Ln } O P- & -15.95753^{* *} & 0.0223 \\ \ln G D P & 25.55886^{* *} & 0.0112 \\ \ln T R D & 7.324387^{*} & 0.0649 \\ \text { Ln } P I & 14.39571^{* *} & 0.0256\end{array}$

long-run estimation

\section{Positive}

\begin{tabular}{lll}
\cline { 2 - 3 } Variable & t-statistics & Probability \\
\hline $\ln \mathrm{OP}+$ & -0.492323 & 0.6563 \\
$\ln \mathrm{OP}-$ & -2.148843 & 0.1208 \\
$\ln$ GDP & -1.129776 & 0.3407 \\
$\ln T R D$ & $3.867606^{* *}$ & 0.0306 \\
$\operatorname{Ln} P I$ & $-3.230316^{* *}$ &
\end{tabular}

\footnotetext{
Diagnostics Test: $\quad$ Statistics value Probability

Serial Correlation LM Test: $0.452179 \quad 0.5077$

Heteroskedasticity Test: $\quad 0.816818 \quad 0.6858$

Normality Test: $\quad 0.392656 \quad 0.82174$

We use the Breusch-Godfrey test for the serial correlation test, Breusch-Pagan-Godfrey test for the heteroskedasticity test and Jarque-Bera for the normality test.

Moreover, to test the reliability of model 4 and 5 we have tested the LM test for serial correlation, heteroskedasticity test as well as the normality of the model. The results for the LM test revealed that the equations accept null of no serial correlation and the heteroskedasticity test show that we can accept the null hypothesis of homoscedasticity. Lastly, there is evidence for normality. Therefore, the outcomes of this study are reliable.
} 
The stability of the model, as well as the short-run and long-run multipliers of oil price increases and decreases have been evaluated. The results revealed that the models of this study are stable and it takes several years for the impact of both increases and decreases in the oil prices to be fully felt.

\section{Conclusion}

This research investigated the effect of the rise and the fall in oil prices on renewable energy in the United States from 1970 through 2019. To study it systematically, a nonlinear ARDL model for renewable energy use was established utilizing GDP, the price of crude oil, population density and price index as independent variables.

The results in general revealed that the rise in crude oil price, GDP and population density will increase renewable energy use in the short run and the long run. However, the increase in price level will reduce the renewable energy use. Moreover, the decrease in oil prices will decrease renewable energy use in the short run and its significant effect will eventually diminish in the long run.

GDP is a clear indicator of income, thus the increase in GDP will eventually increases the demand for renewable energy. Therefore, the increase in economic development (due to the increase in GDP) the US will have enough finance and human capital to invest and adopt more renewable energy.

The rise in population density will increase the US renewable energy use. It is clear that developed countries such as the United States with population that have a comfortable living standards are characterized by high usage of energy. In the advanced nations, there is widespread of modern appliances and different transportation means (International Energy Outlook, 2011). As more energy consumption is required to generate economic growth, energy is anticipated to positively influence the consumption of different types of primary energy including the consumption of renewable energy.

Regarding crude oil prices, the outcomes showed clearly that the rise in oil prices will increases renewable energy use while the fall in crude oil prices will reduce renewable energy. These results are expected as the increase in crude oil prices will encourage the country to find cheaper energy alternatives such as renewable energy. However, the decline in oil prices will reduce the use of renewable energy, as oil becomes a cheaper alternative to renewable energy. 
It is normally recognized that renewable energy is an alternative to crude oil. With adequate availability of natural resources, it is usually more convenient for developed countries to switch from fossil fuels to renewable energy consumption because of the availability of better technologies. Basic economics theory of cross price elasticities believes that there is positive relationship between the price of a substitute good and the demand for the other substitute good. Therefore, a positive influence of oil prices on renewable energy consumption is anticipated as increasing oil prices will encourage households and business to decrease their oil consumptions, patronise energy-efficient gadgets and shift to renewable energy sources. Lastly, the rise in price level will discourage the US population consumption demand for renewable energy as higher price level lowers the value of the US dollar. Therefore, the increase in price level will decreasing the country purchasing power parity reducing the population consumption for goods and services including renewable energy.

From the outcome of this research we can introduce one important recommendation, as oil market is glutted with crude oil driving it prices down, it is the best time for the US government to impose tax on crude oil to raise the amount of funds available for renewable energy research. This suggestion be able to aid the country to rise its energy security by reducing its dependency on imported crude oil and increase the role of renewable energy to be the prime energy source for the United States in the future. In addition, the US government needs to allocate more resources toward enhancing the development of renewable energy increasing its share in the United States energy mix. Moreover, increasing the use of less water intensive sources of renewable energy (such as solar energy) in urban areas is essential to decrease water footprint in the United States major cities. Moreover, it is important to create a more efficient infrastructure that depends on more renewable energy sources such as solar, wind energy, and a better rain water harvest to optimize energy production. In addition, it is important to harmonize trade policies with other major renewable energy producing countries such as China, India, Brazil, South Africa, Japan and so forth to reduce trade barriers on goods that are related to renewable energy. Lastly, since the increase in price index negatively affects the use of renewable energy; it is important for the government to provide incentives for the public such as a lower taxes and lower electricity price utility. This will encourage the US industries to utilize more renewable energy sources to lower the cost of their output. 


\section{DECLARATIONS}

\section{Ethics approval and consent to participate:}

This study follows all ethical practices during writing and interpretations. Consent to participate is not applicable.

\section{Consent for Publication}

Not Applicable

\section{Availability of data and materials}

Data used in this study can be found in the cited link.

The datasets used and analysed during the current study are available in the following placesRenewable energy consumption per capita was obtained from U.S. Energy Information Administration- $2020 \quad$ (International Energy Outlook- 2020)https://www.eia.gov/outlooks/ieo/

GDP, Brent crude oil prices, population density, and price index were retrieved from the World Development Indicators (2020)- https://databank.worldbank.org/source/world$\underline{\text { development-indicators }}$

Trade openness is obtained from the OECD database (2020) - https://stats.oecd.org/

Competing interests

The authors declare that they have no competing interests

\section{Funding}

Not Applicable

\section{Authors' contributions}

- PKS is the Major contributor in developing the idea and writing the Manuscript

- SAS is the major contributor in fixing the methodology and estimation using RALS technique

- UAM was responsible for collecting the data and helping in the interpretation of result 
- IO also helped in the interpretation of result and drafting

\section{References}

Abdo, AB., Li, B., Zhang, X. et al. (2020) Influence of FDI on environmental pollution in selected Arab countries: a spatial econometric analysis perspective. Environmental Science and Pollution Research 27: 28222-28246.

Aguirre, M., Ibikunle G. (2014) Determinants of renewable energy growth: A global sample analysis. Energy Policy, 69: 374-384.

Azam, M. K., A.Q., Zaman K., Ahmad, M. (2015) Factors determining energy consumption: Evidence from Indonesia, Malaysia and Thailand. Renewable and Sustainable Energy Reviews 42: $1123-1131$.

Ben Jebli, M., Ben Youssef, S. \& Apergis, N. (2019) The dynamic linkage between renewable energy, tourism, $\mathrm{CO}_{2}$ emissions, economic growth, foreign direct investment, and trade. Latin America Economic Review 28: 2

Bondia, R.; Ghosh, S.; Kanjilal, K. (2016) International crude oil prices and the stock prices of clean energy and technology companies: Evidence from non-linear cointegration tests with unknown structural breaks. Energy, 101: 558-565.

Cao Hong, Litian Guo, Lin Zhang (2019) Does oil price uncertainty affect renewable energy firms' investment? Evidence from listed firms in China Finance Research Letters, 33: 101-205.

Coban S and Topcu M. (2013) The nexus between financial development and energy consumption in the EU: A dynamic panel data analysis, Energy Economics, 39(C): 81-88.

Dawson, J. W., \& Strazicich, M. C. (2010) Time-series tests of income convergence with two structural breaks: evidence from 29 countries. Applied Economics Letters, 17(9): 909-912.

Dinda, S. (2004) Environmental Kuznets Curve Hypothesis: A Survey. Ecological Economics, 49(4): $431-455$.

Dogan E, Seker F (2016) Determinants of CO2 emissions in the European Union: the role of renewable and non-renewable energy. Renewable Energy 94:429-439

Dogan E., A Aslan (2017) Exploring the relationship among CO2 emissions, real GDP, energy consumption and tourism in the EU and candidate countries: Evidence from panel models robust to 
heterogeneity and cross-sectional dependence, Renewable and Sustainable Energy Reviews, 77: 239246.

Dogan E., Lotz Roula, Altinoz B. (2021) Examining the determinants of renewable energy deployment: Does the choice of indicator matter? International Journal of Energy Research, 17 January 202, https://doi.org/10.1002/er.6413

Energy Information Administration. (2016) Annual Energy Review. Available at: https://www.eia.gov/totalenergy/data/annual/showtext.cfm?t=ptb1001.

Erdogan, S., Okumus, I. \& Guzel, A.E. (2020) Revisiting the Environmental Kuznets Curve hypothesis in OECD countries: the role of renewable, non-renewable energy, and oil prices. Environmental Science and Pollution Research 27: 23655-23663

Ferrer, R., Shahzad, S.J.H., López, R., Jareño, F. (2018) Time and frequency dynamics of connectedness between renewable energy stocks and crude oil prices. Energy Economics 76: 1-20.

Inglesi-Lotz R, E Dogan (2018) The role of renewable versus non-renewable energy to the level of $\mathrm{CO}_{2}$ emissions a panel analysis of sub- Saharan Africa's Big 10 electricity generators. Renewable Energy 123:36-43

International Energy Outlook (2011). Interational Energy Outlook 2011. United States Energy Information Administration. Washington, D.C., USA.

Kapetanios, G., Shin, Y., \& Snell, A. (2003) Testing for a unit root in the nonlinear STAR framework. Journal of Econometrics 112: 359-379.

Kar, M., Nazlioglu, S., Agır, H., (2011) Financial development and economic growth nexus in the MENA countries: bootstrap panel granger causality analysis. Economic Modelling, 28 (1-2): 685693.

Karanfil F., Li, Y. (2015) Electricity consumption and economic growth: exploring panel-specific differences. Energy Policy, 82: 264-77.

Khan, M.A., Ozturk, I. (2020) Examining foreign direct investment and environmental pollution linkage in Asia. Environmental Science and Pollution Research, 27: 7244-7255.

Kruse, R. (2011). A new unit root test against ESTAR based on a class of modified statistics. Statistical Papers, 52(1): 71-85. 
Kyophilavong P., Shahbaz, M., Anwar S., Masood S. (2015) The energy-growth nexus in Thailand: Does trade openness boost up energy consumption. Renewable and Sustainable Energy Reviews, 46: $265-274$.

Lee, J., Strazicich, M. C., \& Meng, M. (2012) Two-step LM unit root tests with trend-breaks. Journal of Statistical and Econometric Methods, 1(2): 81-107.

Li, J., \& Lin, B. (2016) Inter-factor/inter-fuel substitution, carbon intensity, and energy-related CO2 reduction: Empirical evidence from China. Energy Economics, 56: 483-494.

Lin, B., \& Omoju, O. E. (2017). Focusing on the right targets: Economic factors driving non-hydro renewable energy transition. Renewable Energy, 113: 105-105.

Liu, M., Xue, X., Zhou, B. et al. (2019) Population susceptibility differences and effects of air pollution on cardiovascular mortality: epidemiological evidence from a time-series study. Environmental Science and Pollution Research, 26: 15943-15952.

Meng, M., Im, K.S., Lee, J., Tieslau, M.A. (2014) More powerful LM unit root tests with non-normal errors. In R.C. Sickles and W.C. Horrace (Eds.) Festschrift in Honor of Peter Schmidt. New York: Springer, 343-357.

Mudakkar, S.R., Zaman, K., Shakir, H., Arif, M., Naseem, I., Naz, L., (2013) Determinants of energy consumption function in SAARC countries: balancing the odds. Renewable and Sustainable Energy Reviews, 28: 566-574.

Mujtaba Aqib \& Jena P.K. (2021) Analyzing asymmetric impact of economic growth, energy use, FDI inflows, and oil prices on CO2 emissions through NARDL approach, Environmental Science and Pollution Research, Accepted: 20 January 2021 https://doi.org/10.1007/s11356-021-12660-z

Murshed, M., Tanha, M.M. (2020) Oil price shocks and renewable energy transition: Empirical evidence from net oil-importing South Asian economies. Energy, Ecology and Environment https://doi.org/10.1007/s40974-020-00168-0

Nasir., M, I., Nuynh., Tram, H. T. X., (2019) Role of financial development, economic growth \& foreign direct investment in driving climate change: A case of emerging ASEAN. Journal of Environmental Management, 242: 131-141. 
Nicholas Apergis, Bradley T. Ewing, James E. Payne (2021) The asymmetric relationship of oil prices and production on drilling rig trajectory, Resources Policy, 71.

Omri A., Nguyen D.K., (2014) On the determinants of renewable energy consumption: International evidence. Energy, 72: 554-560.

Omri, A., Daly, S., \& Nguyen, D.K. 2015. A robust analysis of the relationship between renewable energy consumption and its main drivers. Applied Economics, 47(28): 2913-2923.

Omri, A., Kahouli, B., (2014) The nexus among foreign investment, domestic capital and economic growth: empirical evidence from the MENA region. Research in Economics, 68(3): 257-263.

Pesaran, M.H., Shin, Y., Smith, R., (2001) Bounds testing approaches to the analysis of level relationships, Journal of Applied Economics, 16: 289-326.

Pham, L. 2019. Do all clean energy stocks respond homogeneously to oil price? Energy Economics, 81: $355-379$.

Rafindadi, A.A., Ozturk, I., (2016) Effects of financial development, economic growth and trade on electricity consumption: Evidence from post-Fukushima Japan. Renewable and. Sustainable Energy Review 54: 1073-1084.

Sadorsky, P., (2010) The impact of financial development on energy consumption in emerging economies. Energy Policy, 38: 2528-2535.

Schmalensee, R., Bulovic V. (2015) The Future of Solar Energy: An Interdisciplinary MIT Study, Available at: https://energy.mit.edu/wp-content/uploads/2015/05/MITEI-The-Future-of-Solar-

\section{Energy.pdf}

Schumpeter, J.A., (1911) The Theory of Economic Development. Harvard University Press, Cambridge, MA.

Shahbaz, M., Solarin, S. A., Ozturk, I. (2016) Environmental Kuznets Curve hypothesis and the role of globalization in selected African countries. Ecological Indicators, 67: 623-636.

Shin, Y., Yu, B., \& Greenwood-Nimmo, M. (2011) Modelling Asymmetric Cointegration and Dynamic Multiplier in a Nonlinear ARDL Framework. Mimeo, New York, NY.

Stern, N., 1989. The economics of development: a survey. Economic Journal 100: 597-685.

United Nations. (2015) G7 Renewable Energy Initiative, Government Announcement, Action 2015 
World Bank (2020) Renewable Energy. Financial, Service Sector and Sustainable Development Department, World Bank Group.

Zaidi, A. S. H, Zafar, M. W., Shahbaz, M., Hou, F. (2019) Dynamic linkages between globalization, financial development and carbon emissions: Evidence from Asia Pacific Economic Cooperation countries. Journal of Cleaner Production, 228: 533-543. 